\title{
Stylistica of Maulid Simtud Durar's Repetition Created by Habib Ali Bin Muhammad Husein Al-Habsyi
}

\author{
Nur Huda ${ }^{1}$ Ihsan Sa'dudin ${ }^{2 *}$ \\ ${ }^{1}$ Al Quran and Interpretation Study Program STAI Al-Anwar Sarang Rembang, Indonesia \\ ${ }^{2}$ Arabic Language and Literature Study Program, IAIN Syekh Nurjati Cirebon, Indonesia
}

\author{
Article History: \\ Received : September 20, 2019 \\ Revised : October 28, 2019 \\ Accepted : November 13, 2019 \\ Published : December 01, 2019
}

\section{Keywords:}

Asonance; Epanalepsis; Epizeuxis; Symploce

*Correspondence Address: ihsan.sadudin@syekhnurjati.ac.id

\begin{abstract}
This study aims to describe the repetition and its effects in "Maulid Simtud Durar" by Habib Ali bin Muhammad Husein AlHabsyi. This research is a qualitative study using descriptive methods. Qualitative research is one of the research procedures that analyzes descriptive data in the form of observed speech or writing. Descriptive method is aimed at describing and analyzing data about repetition language style in the maulid simtud durar. Repetition is a form of repetition, both in terms of sounds, syllables, or sentence parts that are considered important to put pressure in accordance with the expected context. This research confirms the existence of rhetorical language in the form of repetition contained and scattered in the maulid simtud durar to convey meaning and abstract thought then conveyed concretely through reps to give greater influence and effect in the hearts and minds of readers. The results of this study found six types of repetition, each of which was Tikrar Lafdzi (epanalepsis), Tikrar Taukidi (Epizueksis), Tajanus Sawti (Asonance), Mawjah Basitah (Simploke), Jinas Tam (Paranomasia), and Jinas Ghairu Tam. This research explains the ability of repetitive language styles in the maulid simtud durar to describe abstract meaning and thought, especially the emphasis on magical things and something amazing, whic the meaning is transformed into a repetition, because something that is visible and concrete can strengthen meaning and can have an effect that bigger in heart and mind.
\end{abstract}

\section{Introduction}

This study will examine the phenomenon of repetition and the effects arising in one of the book created by a well-known scholar, Habib Ali ibn Muhammad Husein alHabsyi, Maulid Simtud Durar, one of the books that contains the history of the prophet Muhammad which is often recited in Majlis. This is important to understand because repetition is able to influence the fluency of the reader and the ability of the reader to be able to influence the intent or not. 
The Book named Maulid Simtud Durar (as known as MSD) is a literary work that is familiar among Muslims, especially for lovers of Maulid (read: the history of birth) of prophet Muhammad. The complete book entitled Simtud Durar fi Akhbar Maulid Khairil Basyar wa Ma Lahu min Akhlak wa Aushaf wa Syiar (A Story of the Most Important Human Being Birth; Morals, Attributes, and Biography) does talk about the history of the prophet. However, that is not the main problem in this study. The book written by Habib Ali bin Muhammad Husein al-Habsyi is presented in a beautiful language style and full of aesthetic values, including the style of repetition language. The book is no less interesting than the other masterpieces that were popular among Muslims, namely the book of Maulid al-Barzanji by Sayyid Ja'far bin Husein bin Abdul Karim al-Barzanji and the book of Maulid al-Dziba'i by Shaykh Abdurrahman bin Ali ibn Muhammad ibn Umar ibn Ali ibn Yusuf ibn Umar Al-Dziba'i as-Syaibani.

For example the repetition in Simtud Durar article 13:

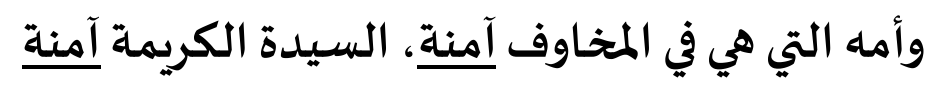

In the example above found the same two words. The word aminah is conveyed repeatedly by the author but the meaning and purpose of the two words are not the same. By paying attention to the form of the repetition, the beauty of the language style used is more obvious. Words may be the same but the meanings are different. The emphasis on the word shows the high aesthetic and literary values of the repetitive language style. The beauty of the language which contained in MSD shows that the author is not only an expert in historical matters, but also an expert in conveying ideas through various styles of language with high aesthetic value. The author is able to combine content and expression. So it is not excessive if the author deserves to be called a writer or litterateur.

Keraf states that in a literary work there are at least components of content and expression. This opinion is based on a concept adopted in the Renaissance. Both of these components more or less affect the quality of literary works. Content in other terms is said to be an abstract idea that is about to be expressed, while expression is a way of conveying ideas in a more concrete form. In this case, expression has a significant role. A good idea in a literary work that is not expressed with a good "wrap" will have an impact on the reader's difficulty in understanding the idea. Another case, an idea that is mediocre or not too good, but wrapped in a neat and nice way, it will surely give an appeal and 
easily understood by the reader. ${ }^{1}$ In other words, to obtain the integrity of meaning requires proper diction and style of language. The most basic reason is diction and language style created in concrete form will be very helpful in interpreting quickly the meaning. ${ }^{2}$

It seems appropriate to say that the study of stylistics is a study that talks about how language styles are processed in such a way then produced and expressed in attractive 'packages'. The 'package' is then expected to be able to express ideas in a more concrete and interesting form. Stylistics as said by Ratna is the science used to investigate the use of language in literary studies, namely by determining the sides of its beauty. The rhetoric or stylistic style of language as stated by Keraf also views aspects of constructive deviations regarding language to obtain certain effects. ${ }^{3}$ In addition, stylistics in the scope of literature are used to explain the relationship between language and artistic functions as well as their meaning. ${ }^{4}$

Usually, when reading a literary work or certain stories that are contained in a story, a person suddenly feels interested, engrossed, and devoted even though basically he does not know the exact meaning of the story. The interest, preoccupation, and solemnity experienced include arising from the style of language used by the author. In other words, the style of the author's language can influence the reader even if only seen from the side of birth alone. Moreover, if the reader knows the meanings, it will show how beautiful the book is. The types of styles of language certainly vary according to the perspectives of linguists. Ratna classifies the language styles into four parts, there are comparison style, affirmation, innuendo, and contradiction. ${ }^{5}$ Likewise, Tarigan classifies the language styles into four parts, there are repetition, contradiction, comparison, and interrelation. $^{6}$

This research will focus on the study of repetition, especially the theory of Gorys Keraf. The basic reason for the selection of Keraf figures here is because of the existence of clear explanations and exposures of the theory, in addition to the fact that Keraf often

\footnotetext{
${ }^{1}$ Gorys Keraf, Diksi Dan Gaya Bahasa (Jakarta: Gramedia Pustaka Utama, 2010), p. 112.

2 Rosmini, Sugit Zulianto, and Sitti Harisah, 'Diksi Dan Gaya Bahasa Syair Lagu Karya Didi Kempot', Jurnal Bahasantodea, 5.2 (2017), 92-101.

${ }^{3}$ Gorys Keraf, p. 129.

${ }^{4}$ Akhmad Syahid and Ika Selviana, 'Gaya Bahasa Dalam Lirik Lagu Shalawat Nissa Sabyan Dan Implikasinya Terhadap Studi Stilistika (Ilmu Uslub)', Al-Fathin: Jurnal Bahasa Dan Sastra Arab, 1 (2019), p. 193-207.

5 Nyoman Kutha Ratna, Stilistika: Kajian Puitika Bahasa, Sastra, Dan Budaya (Yogyakarta: Pustaka Pelajar, 2013), p. 3.
} 
presents theories as well as clear examples. Simtud Durar by Habib Ali bin Muhammad Husein Al-Habsyi is one of the books that contains the history and biography of the prophet (read: maulid) Muhammad peace be upon him. Maulid Simtud Durar (read : MSD) is one of the Maulid books which is now often used in Majlis on the one side, in addition to other Maulid books which are well known in the community, such as Maulid al-Barjanji and Maulid Adz-Dhiba'i. On the other hand, MSD is included as a book of birth which has a literary nuance and is filled with beautiful language styles. The beauty of the language style among them is shown by the style of repetition.

Study of repetition, in several articles have been reviewed by several researchers. Certainly, each article has different similarities and characteristics. One of them is the study of Achmad Syukron Abidin entitled Nilai-nilai Akidah dan Akhlak dalam Kitab Simtud Durar Karya Habib Ali bin Muhammad Al-Habsy (Analisis Isi Akidah dan Akhlak) (The Values of the Aqeedah and Morals in the Book of Simtud Durar by Habib Ali bin Muhammad Al-Habsy (Analysis of the Content of the Aqeedah and Morals)). He examines the values of faith and morals in the book of Simtud Durar. The theme of this research lies in the material object, which is the same study taken in the book of the book of Simtud Durar by Habib Ali bin Muhammad Husein Al-Habsyi but different in approach. $^{7}$

Habib in his research entitled Stilistika Pengulangan sebagai Transfer Ideologi (Telaah atas Pidato Politik Sayyed Hasan Nasrullah) (Repetition Stilistics as Transfer of Ideology (Study of Sayyed Hasan Nasrullah's Political Speech) examines the relationship between repetition and political ideology of Sayyed Hasan. The research seeks to analyze Sayyed Nasrullah's two speeches during the conflict between Hezbollah and Israel during 2006. In addition, the core of this research is how Sayyid Nasrullah used repetition in his oration as his political strategy and also examined what the function, type and purpose of repetition in his oration. ${ }^{8}$

Rohmat Anang Purdi's research entitled Istia'rah wa Jamaliha fi Simtud Durar focuses on the study of Lughawi. The similarity in this research is in terms of material objects, but different in approach. The researcher examines the identification of the form

\footnotetext{
${ }^{6}$ Henry Guntur Tarigan, Pengajaran Gaya Bahasa (Bandung: Angkasa, 2013), p. 7-91.

7 Achmad Syukron Abidin, 'Nilai-Nilai Aqidah Dan Ahlak Dalam Kitab Simtut Durar Karya Habib Ali Bin Muhammad Al-Habsyi', El-Wasathiya: Jurnal Studi Agama, 7.1 (2019), 1-25.

${ }^{8}$ Habib, 'Stilistika Pengulangan Sebagai Trasnfer Ideologi (Telaah Atas Pidato Politik Sayyed Hasan Nasrullah)', TAMADDUN: Jurnal Kebudayaan Dan Sastra Islam, 14.1 (2014), 63-80.
} 
of isti'arah in the symbol of durar and reveals the secret of the beauty of isti'arah which basically cannot be separated from the value of tasybih in two aspects, namely in the arrangement of words or lafadz and tasybih aspects that are difficult to reach by the heart except by people with an artistic spirit, because it needs a depth thought to get the hidden meaning of tasybih. ${ }^{9}$

Next is Rifka Diana Susilowati's research with the title Al-Suja 'fi Simth AlDurar: Dirasah Balaghiyah. This research focuses on the use of poetic language style or the matching of the two ending words in the book as well as the kinds found in the simtud durar. ${ }^{10}$ Saiful Hidayat, in his research entitled Kalimat Berita dalam Kitab Simtudduror, tried to describe the kalam khobar according to the diversity of speech partners. In addition, the focus of this research is to explain the intent and purpose of kalam khobar. ${ }^{11}$

From some of the studies that have been presented, it is clear that the differences and substance are present in this study. Some studies have not yet touched on the realm of study of repetition which is focused on being analyzed in the book of Maulid Simtud Durar by Habib Ali bin Muhammad Husein Al-Habsy. Especially to touch the realm of the effects caused in the use of repetition. Therefore, the authors assume that this article will add insight into the language style of repetition in MSD. In the end, this paper is expected to be able to reveal in depth the forms of repetition in MSD as well as to explain clearly the effects arising from the use of repetition. Besides that, this paper is expected to be able to inspire research on repetition in other Maulid books.

\section{Theoretical Support}

The study of language style in literary works is known as stylistics. The origin of stylistics lexically means the study of style or language style. Ratna stated that stylistic (style of language) is a way to arrange a language with the aim of obtaining beauty or aesthetic aspects in language or literary works. So in this case Ratna considers that stylistics is part or element of the literature itself. ${ }^{12}$ While stylistics, according to Al-

\footnotetext{
${ }^{9}$ Rohmat Anang Purdi, 'Isti'arah Wa Jamaaliha Fi Simtud Durar', Thesis, (UIN Sunan Ampel Surabaya, 2016).

${ }^{10}$ Rifka Diana Susilowati, 'Al Suja' Fi Simth Al Durar : Dirasah Balaghiyah', Thesis, (UIN Sunan Ampel Surabaya, 2014).

${ }^{11}$ Saiful Hidayat, 'Kalimat Berita Dalam Kitab Maulid Simtudduror', SKRIPSI Jurusan Sastra Arab-Fakultas Sastra UM (Universitas Negeri Malang, 2015).

12 Ratna.
} 
Ma'ruf, is a study of the use of language in literary works. The form includes all the empowerment of language potential, characteristics and uniqueness of language, sound style, diction, discourse to figurative or figurative language. ${ }^{13}$

Ali stated that stylistics which in Arabic literature is called $u s l u b$ is a special way used by writers or authors to convey thoughts and feelings into special languages as well. Interesting or not a style of language is determined by the author's success rate in conveying his thoughts to others. Language style determines a person's characteristics ${ }^{14}$, author's soul and personality. Language style and the right choice of words will bring up the right ideas or ideas in the imagination of the reader or listener exactly as the author feels and thinks. ${ }^{15}$ In other words, even though the contents or ideas are similar, each author is able to present other characters in writing. This is what is later called a creative and innovative work. ${ }^{16}$

While Al-Zarkasyi states that tikrar or repetition is the repetition of words or their equivalent to determine a meaning. ${ }^{17}$ Subhi al-Faqi said that repetition is mentioning the same or equivalent words, phrases, sentences or paragraphs to achieve various objectives, especially the coherence of texts between spatial elements. ${ }^{18}$ Repetition is part of the majas with the characteristic repetition of words / phrases that perform functions as a means of prioritizing and obtaining certain effects. Repetition in the world of writing has the difference between repetition as a masterpiece and repetition as a form of writing weakness of novice writers. Repetition as majas has a form of repetition for the benefit of certain constituents, not repetition that does not clearly carry out its function as a means of importance. But another thing, repetition that is not as a background is motivated by the inability of the writer in varying the lingual units to form repetitions of the form of

13 Arina Dicka Maretta, Elisabeth Nugrahani Eko Wardani, and Atikah Anindiyarini, 'Analisis Stilistika Dan Nilai Pendidikan Karakter Dalam Lirik-Lirik Lagu Fourtwnty Album Lelaku Serta Relevensinya Sebagi Bahan Ajar Bahasa Indonesia Tingkat SMA', BASASTRA Jurnal Pendidikan Bahasa, Sastra Indonesia Dan Pengajarannya, 6.2 (2019), 31-39.

${ }^{14}$ Habibullah Ali Ibrahim Ali, 'Dirasah Al-Uslub Wa Al-Uslubiyah Fi Naqd Al-Araby', LiNGUA: Jurnal Ilmu Bahasa Dan Sastra, 10.1 (2015), 45-54 <https://doi.org/10.18860/ling.v10i1.3033>.

15 Nur Rochmah Fatoni, 'Kekhasan Diksi Valentin Simajuntak Pada Piala Presiden 2017', Adabiyyat : Jurnal Bahasa Dan Sastra, I.2 (2017), 223-47.

16 Ali.

${ }^{17}$ Firas Yahya Abdul Jalil, 'The Repetition of the Words of Quranic Texts and Their Impact on the Diversity of Meaning', Anbar University Journal of Islamic Sciences, 10.40 (2019), 1-28.

${ }^{18}$ Saeed Abdul Hamid, 'Impact of Redundancy in the Quranic Text Consistency Study in Light Text Linguistics', Al-Adab Journal, 129, 2019, 791-808. 
lexis which complicates the reader. ${ }^{19}$ Thus, two or more repetitions that do not have clear reasons and goals, as al-Hasyimi said, are not the meaning of tikrar in the balaghah perspective. The repetition is only tathwil (extend) or hasyw (word wastage). ${ }^{20}$

Zabidi states that repetition is one style of language and media of expression that functions to express the depth of a text and expose various kinds of authors' feelings. Repetition is one mirror that reflects the intensity of feelings that accumulates in the creative author. ${ }^{21}$ It is said to be creative because the accuracy and fidelity of the author when using repetition have a significant role in optimizing the function of repetition which incidentally helps in emphasizing intentions and giving certain effects. ${ }^{22}$ Repetition is the use of forms repeatedly, either in whole or in part, in a sentence or sentence clusters in a paragraph or discourse. Therefore, from several types of language styles, Keraf includes reps in the category of language style based on sentence structure. ${ }^{23}$ Repetition is used as an emphasis on the element that is repeated, so that the element that gets repetition is the element that is emphasized. Repetition of words that have the same referent with variation on the linguistic unit that is successively repeated will be able to present a far more interesting text. ${ }^{24}$

Yassin states that repetition is one of the most important literary discourse phenomena. Repetition is one of the artistic phenomena and part of the most prominent linguistic style that is able to manifest semantic and aesthetic dimensions in literary discourse. In addition, the repetitive language style motivates the reader to look for and see the semantic dimensions in literary works ${ }^{25}$ From some of the definitions and statements of the experts above it can be concluded that repetition is a style of language that represents repetition of words, phrases or even paragraphs in any text used by the author for something important that is intended and conveyed to the reader.

\footnotetext{
${ }^{19}$ Sidiq Aji Pamungkas and Kundharu Saddono, 'Repetisi Dan Fungsinya Dalam Novel Di Tanah Lada Karya Ziggy Zezsyazeoviennazabrizkie: Analisis Stilistika’, METASASTRA: Jurnal Penelitian Sastra, 11.1 (2018), 113.

20 Nur Fauzi, Syamsul Hadi, and Thoyyib, 'Bentuk Repetisi Linguistik Dalam Al-Quran', LiNGUA: Jurnal Ilmu Bahasa Dan Sastra, 9.1 (2014), 31-40.

21 Jawad Rangbar and Ameen Nadhri, 'Repetition and Its Styles in the Complete Poetic Collectioe', Basic Education College Magazine For Educational and Humanities Sciences, 37, 2018, 5265.

22 Pamungkas and Saddono.

${ }^{23}$ Ninit Alfianika, 'Bahasa Betawi Dan Gaya Bahasa Repetisi Dalam Ceramah Ustad Yusuf Mansur Progam Wisata Hati Di ANTV', Jurnal Gramatika, 1.1 (2015), 111-22.

${ }^{24}$ I Dewa Putu Wijana, 'Repetisi Dalam Karangan Mahasiswa Dan Penanganannya', Humaniora, 18.1 (2006), 37-45.

${ }^{25}$ Moataz Qusay Yassin, 'The Aesthetic of Repetition in the Poetry of Ahmed Matar', The Arab Gulf, 46.1-2 (2018), 206-37.
} 
The function of repetition is to emphasize and to emphasize in the appropriate context. $^{26}$ The repetition function according to Al-Jaff there are at least three main functions. First, empathic functions are focused on meaning. Second, rhythmic or something that related to the rhythm functions. Third, the aesthetic function that influences the appearance of the text. Specifically Johnstone highlights the function of Arabic reps. He added that Arabic is a persuasive language that needs to be repeated. The greater or more often repeated, the more important is information. ${ }^{27}$ Meanwhile, Tannen mentions that the first function of repetition was to unite the different parts of a text into one and make it coherent. ${ }^{28}$

\section{Method}

This research is a qualitative study using descriptive methods. This research attempts to describe the linguistic phenomena contained in Simtud Durar by Habib Ali bin Husain al-Habsyi. The aim is to obtain a detailed description relating to the style of language, especially the style of repetition language. In data collection techniques, researchers used the method of listening with tapping techniques. Mahsun states that listening is not only related to spoken language, but also written language. In the case of written-tapping technique, the researcher conducts tapping not with the person who is speaking but in the form of written language such as ancient texts, narrative texts, languages on mass media. ${ }^{29}$ The steps in data collection are (1) careful and accurate reading of MSD texts from beginning to end, (2) marking and re-recording narrative texts that become data in research, and (3) inventorying words related to style repetition language using a data inventory format.

After all the data that has been collected, the data is analyzed by (1) identifying the data in accordance with the repetition language style in MSD, (2) classifying data based on the theory that becomes the reference, (3) analyzing the data by recording words or sentences in MSD relating to repetition language style (5) interpreting data that

\footnotetext{
${ }^{26}$ Edin Parwati, 'Kohesi Leksikal Repetisi Pada Wacana Wayang Durangpo Dalam Surat Kabar Harian Jawa Pos Edisi Februari-April 2010’, Jurnal Artikulasi, 12.2 (2011), 807-16.

${ }^{27}$ Barbara Johnstone, Repetition in Arabic Discourse: Paradigms, Syntagms, and the Ecology of Language (Amsterdam: John Benjamins Publishing, 1991), p 1.

${ }^{28}$ Roghayeh Farsi, 'Repetition and Reactance in Graham's “Underneath" Poems', International Journal of Applied Linguistics and English Literature, 6.6 (2017), 223-34

${ }^{29}$ M.S Mahsun, Metode Penelitian Bahasa Metode Penelitian Bahasa: Tahapan Strategi Metode Dan Tekniknya (Jakarta: Raja Grafindo Persada, 2014), p. 92-93.
} 
has been analyzed in accordance with the theory, and (6) summarizing the results of data description by writing a report.

\section{Result and Discussion}

The results of this study indicate that in MSD there are 6 (six) repetition of language styles. The six styles of repetition are scattered in several texts (read: chapters) of the 16 chapters contained in the book. To find out the type of repetition and its effects, the researcher will analyze it in detail as follows:

\section{a. Tikrar Lafdzi (epanalepsis)}

Epanalepsis is also known as diaphora. In Arabic literature epanalepsis is called tikrar lafdzi..$^{30}$ Epanalepsis is the repetition of the last word in a line, clause, or sentence by repeating the first word.

Table 1. Fourth Section

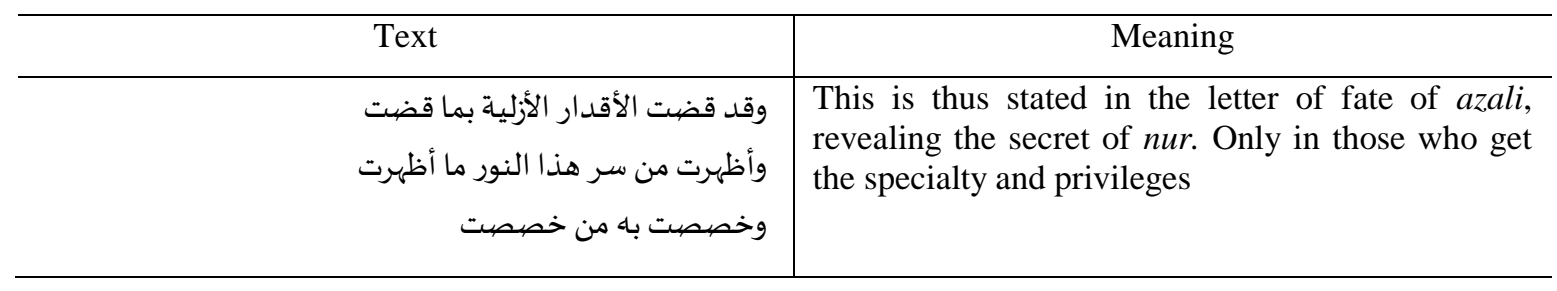

In the maulid fragment above there is a repetition of the word قضت(set) which

is then repeated at the end of the sentence. Likewise the words أظهرت(expressing) and the word خصصصت (specializing) are repeated in the final sequence. This language style, as according to Keraf is called epanalepsis.

The repetition illustrates that the author really put real pressure on the issue of the faith of the people of Muhammad. The author affirms that Allah also reveals the privileges and secrets of nur that move from the noble wombs. Allah also specializes in certain people who are clean and pure. Thus the function of repetition as an emphasis or affirmation above is able to create its own effects for the listener, namely the effect of the existence of something very basic and emphasized, also no need to doubt the truth. In

${ }^{30}$ Muhammad Ali Al-Khuli, A Dictionary of Theoretical Linguistics (Lebanon: Librairie du Libani, 1982), p. 86. 
addition, Allah indeed devoted the prophet Muhammad as the only prophet which His Nur was secured from the beginning to the end of the prophets.

Table 2. Tenth Section

\begin{tabular}{r|c}
\hline Text & Meaning \\
\hline $\begin{array}{r}\text { ثم أخرجوا من قلبه ما أخرجوه } \\
\text { أودموا فيه من أسرار العلم والحمة ما أودعوه }\end{array}$ & $\begin{array}{l}\text { Then they bring out what they spend, then hide the } \\
\text { secrets of science and wisdom into it }\end{array}$ \\
\hline
\end{tabular}

The style of epanalepsis also lies in the words أودعوا أخرجوا. This style clearly creates its own effect for the reader or listener. Especially, if the reader and listener know a little or a lot about Arabic, they will be very stunned and wide-eyed when they hear the piece of the birth or Maulid. That is because the author strongly emphasizes the two words above which are really the will and command of Allah SWT. The author wanted to emphasize with strong affirmation that the process of cleavage of the Prophet's chest did indeed occur, not only once, even many times.

Table 3. $13^{\text {th }}$ section

\begin{tabular}{|c|c|}
\hline Text & Meaning \\
\hline فأوحق إلى من عبل علمها بما اتصلى الله عليه وسلم في تلك الحضرة من سرها ما عقل & $\begin{array}{l}\text { Lots of subtle experiences of the Prophet attached to } \\
\text { his soul, and knowledge and knowledge achieved. } \\
\text { When God reveals to His servants what is revealed. }\end{array}$ \\
\hline
\end{tabular}

Epanalepsic language style is also found in the nasr section above. The author

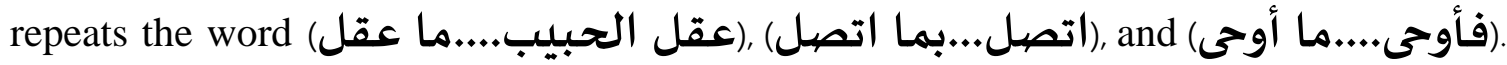
The author here wants to give effect to the reader that the spiritual experience of the prophet is extraordinary. The knowledge and wisdom received by the prophet Muhammad is also incomparable and is not had by other prophets. The obligation to pray five times a day is a proof of the revelation he received directly through mi'raj, unlike most prophets who received commands through revelation in their kitab. The prophet's revelation, the five daily prayers, was conveyed by Allah through their "encounter". Therefore, it is truly wonderful for the author to use the style of epanalepsis, namely by emphasizing the desired objects and events. 
The findings above are examples of epanalepsic language styles in the form of verbs. Researchers also found several examples of epanalepsic language styles in the form of nouns.

Table 4. 3th Section

\begin{tabular}{|c|c|}
\hline Text & Meaning \\
\hline 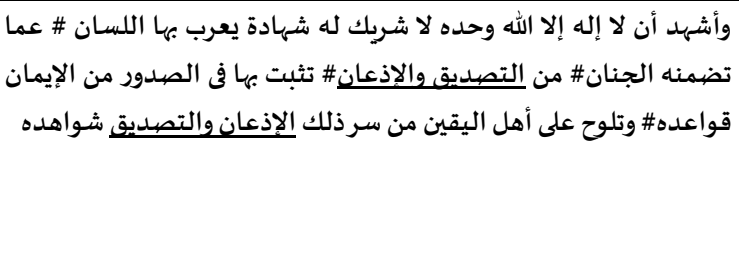 & $\begin{array}{l}\text { I bear witness that there is no god but Allah. } \\
\text { Almighty, there is nothing compared with Him. } \\
\text { Witness is spoken verbally. Express sincerity and } \\
\text { obedience contained in the heartstrings. Strengthen } \\
\text { the faith deeply embedded in their heart. The secret } \\
\text { of its nature seems only to those who are sincere } \\
\text { and obedient, without the slightest doubt. }\end{array}$ \\
\hline
\end{tabular}

Table 5. $5^{\text {th }}$ Section

And the highest behavior among all behaviours

The author repeats the words التصيديق (sincerity), الإذعان(submission), and the

word الشمائل (behavior) in the two tables above. The author deliberately suppresses and reinforces the purpose of the repetition. The issue of faith must indeed be emphasized by a sincere form of justification in terms of speech, action, and submission to Allah SWT. Likewise the author confirms that the prophet Muhammad. has the most perfect temperament or temperament among all creatures.

Of the various examples available, of course these repetitions have aesthetic values, especially in terms of musicalization. The rhythm presented by the author makes the reader or listener feel pleasure and not be bored with reading and listening further. This beauty is also found in poems of high aesthetic value. For example, the style of epanalepsis was also found in one of the poems of Ibn Jabir al-Dharir, an Andalusian writer who was born in 1298 AD He composed poetry with the theme of Madh (praise) which was intended for the Prophet and his companions. In one verse of his poem it says:

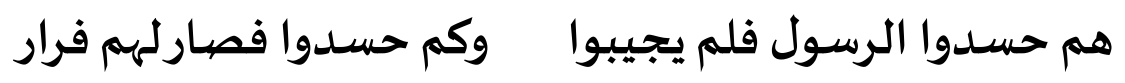

Ibn Jabir in one of the fragments of the poem really made use of the repetition function. The word حسسدوا is repeated twice. He wanted to emphasize that the condition of the prophet and friends in Mecca was really depressed. The people of Mecca at that 
time were really jealous of the prophet so it was time for the prophet and friends to decide to flee and migrate to Medina. Here, the poet reader is brought by the author to imagine the condition of the prophet and his friends who are no longer comfortable with scolding, sneering, and even the threat of Meccan infidels. ${ }^{31}$

\section{b. Tikrar Taukidi (Epizeuxis)}

Epizeuxis is a direct repetition, repetitive forms repeated successively in one idea. ${ }^{32}$ In Arabic literature, Epizeuxis is often referred to as Tirar Taukidi. ${ }^{33}$ The use of epizeuxical language styles is usually used in the construction of dense ideas, also briefly.

Table 6. 2 th Section

\begin{tabular}{|c|c|}
\hline Text & Meaning \\
\hline بانتشـار فضلى الحق فى عالم قدسه الواسع \# تجليا قضى والشـاسع & $\begin{array}{l}\text { Almighty God does Tajalli (Divine Self- } \\
\text { manifestation) in His vast holy nature. Establishing } \\
\text { the spread of His gifts to the near and far is no } \\
\text { exception. }\end{array}$ \\
\hline
\end{tabular}

Table 7. 3th Section

\begin{tabular}{c|l}
\hline Text & \multicolumn{1}{|c}{ Meaning } \\
\hline وأشهد أن لا إله إلا الله وحده لا شريك له شهادة يعرب بها اللسان & $\begin{array}{l}\text { I bear witness there is no god but Allah. } \\
\text { Almighty, there is nothing compared with Him. } \\
\text { The witness is spoken verbally }\end{array}$ \\
\hline
\end{tabular}

Table 8. $15^{\text {th }}$ Section

\begin{tabular}{l|l}
\hline Text & \multicolumn{1}{c}{ Meaning } \\
\hline إذا دعا المسكين أجابه إجابة معجلة & $\begin{array}{l}\text { When the poor call for Him, He is always } \\
\text { responsive to fulfill it immediately }\end{array}$ \\
\hline
\end{tabular}

In the Simtud Durar excerpt above, the author mentions the words تجلى and

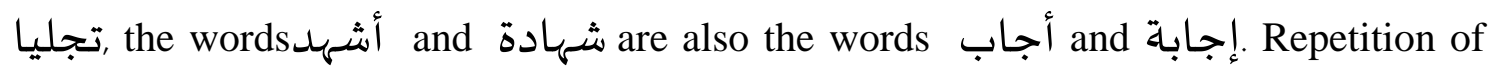
words in one idea in a row deliberately is presented by the author to provide its own pressure. First, the author wants to emphasize that God's grace is expansive. The

31 Abdul Karim Fadhil, 'Al-Tikrar Fi Syi’ri Ibnu Jabir Al-Dharir Al-Andalusi', Jurisprudence Faculty Journal, 19, 2014, 186-223.

${ }^{32}$ Keraf, p. 127

${ }^{33}$ Al-Khuli, p. 58 
vastness of the gift is manifested in the tajalli of Allah. Secondly, a servant's witness is really not enough with feeling only, but it needs to be said. Then the author really emphasizes this point with repetition. Third, the author affirms one of the praiseworthy qualities of the prophet Muhammad which he did not discriminate against the social status of society between the rich and the poor, they are in the same statue. In fact, the prophet gladly attended the invitation of the poor if needed. The effect that arises for the reader is full attention to the reading.

To reinforce the above opinion, the writer will compare with one piece of Ibn Zaidun's gazal poetry (love poem) in his diwan.

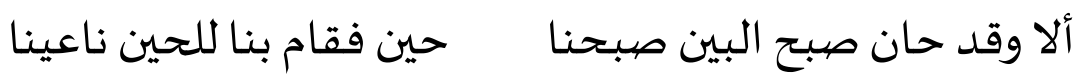

Ibn Zaidun wanted to emphasize the meaning of sadness by using a form of repetition. The words صبح and حان are repeated to describe the sadness that is so deep because they do not want to be separated from loved ones. Farewell (البين) is equated with death (الناعي). So, the effect that arises is the reader is led to the condition of pain because of being left by a lover. What happens is that tears are unavoidable. ${ }^{34}$

\section{c. Tajanus Sawti (Asonance)}

Asonance is a style of language in the form of repetition of the same vowel sounds. Usually this type of language style is often used in poetry or prose works. ${ }^{35} \mathrm{In}$ Arabic literate, this style of language is often referred to as tajanus sawti. ${ }^{36}$

Table 9. Third Section

\begin{tabular}{r|l}
\hline Text & \multicolumn{1}{c}{ Meaning } \\
\hline اللهم صل وسلم بأجل الصلوات وأجمعيا & $\begin{array}{l}\text { O Allah, bestow the greatest blessings and all- } \\
\text { encompassing salutations, extremely holy, far- } \\
\text { reaching }\end{array}$ \\
\hline
\end{tabular}

${ }^{34}$ Nadia Fathi Hadi, 'Repetition Significance in Ibn Zaidoun's Noun-Rhymed Poem', Jurnal Adab AL Rafidayn, 68, 2013, 149-78.

35 Keraf, p. 130

${ }^{36}$ Al-Khuli, p. 25 
In the Simtud Durar section above there is the style of asonance in the form of the words وأوسعها (including everything) and وأجمعها (very wide range of outreach). At the end of the word, the same vocal letters are consistently chanted, i.e they end with a vowel a. So with a beautiful effect will appear beauty and comfort in the soul, especially connoisseurs of language. In addition, another effect that can be felt is the emphasis in the expected meaning the same as what is felt by the author, namely the abundance of prayers offered to the great prophet Muhammad PBUH.

As a comparison, Ridlo in his research mentioned the style of asonance in one of the diwan ash-Shafi'i stanzas. For example:

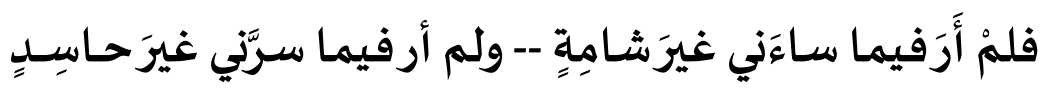

I never saw when I was having a hard time they were happy

And when I was happy they were spiteful

In the poem there is a style of asonation language, it can be seen in the whole stanza that has the same vocal and balanced from the beginning to the end of the stanza. The whole vowel sounds are saani/i, syamiti/i, sarrani/i, and hasidi/i which are presented sequentially and in balance. That way the effect that arises is the beauty of the sound and emphasis on the meaning contained in the verse. ${ }^{37}$

\section{d. Mawjah Basithah (Symploce)}

Symploce is a repetition that is located at the beginning and end of a sentence in no order. ${ }^{38}$ The aim is to explain or emphasize repeated meanings. ${ }^{39}$ In Arabic literature, Symploce is often referred to as Mawjah Basithah. ${ }^{40}$

Table 10. $9^{\text {th }}$ Section

\begin{tabular}{|c|c|}
\hline Text & Meaning \\
\hline 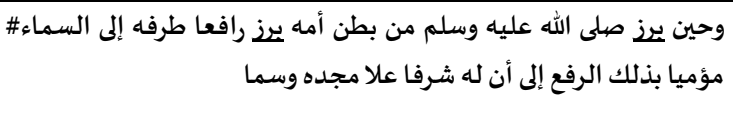 & $\begin{array}{l}\text { And at the time, when the Prophet was born by his } \\
\text { mother, he was born while starring to the sky. As a } \\
\text { gesture he got glory and high honor. }\end{array}$ \\
\hline
\end{tabular}

37 Abdullah Ridlo, 'Kompleksitas Gaya Bahasa Diwan Al-Imam Asy-Syafi'i (Studi Analisis Stilistika)', Thesis, (Yogyakarta : Pascasarjana UIN Sunan Kalijaga, 2017), p. 78.

${ }^{38}$ Keraf, p. 128

${ }^{39}$ Syihabuddin Qalyubi, Stilistika Al-Qur'an Pengantar Orientasi Studi Al-Qur'an, 2nd edn (Yogyakarta: Belukar, 2008), p. 72. 
On the Simtud Durar piece above there is a Symploce language style. This Symploce patterned repetition is written in the word برز برز من بطن أمه . رافعا طرفه Through this repetition there will be a certain effect in meaning, namely the effect carried on the amazing atmosphere that occurs at dawn. It was an extraordinary event when the prophet Muhammad was born. The Prophet was born in a state of prostration then looked at the sky. So that unconsciously every language connoisseur will feel a situation that is amazing and astonished by the power of Allah SWT.

This style is also used by Dr. Ali Majid al-Budaeri, a genuine poet from Iraq. One of the Symploce language styles in the poem is as follows:

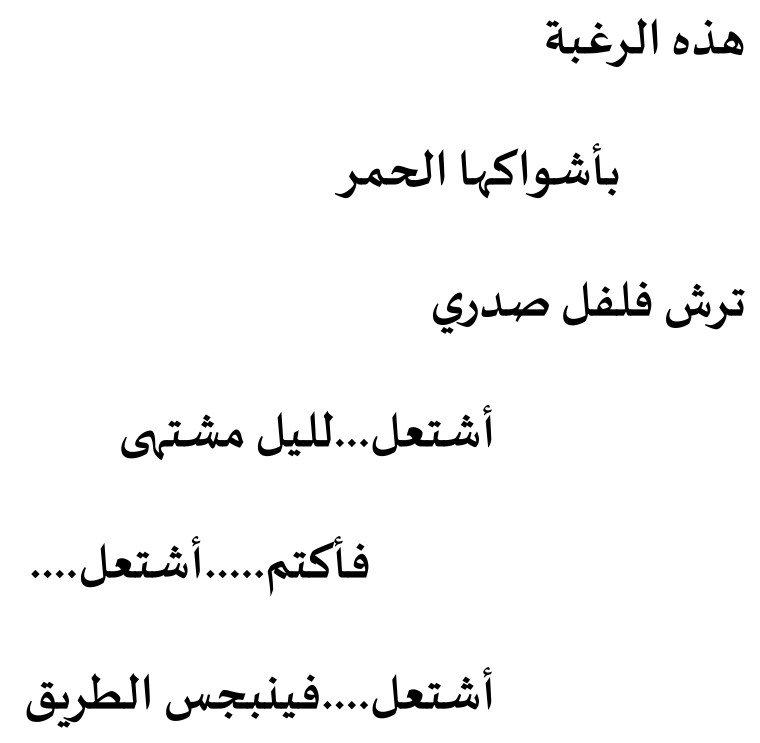

The Symploce form is found in the word أشتعل which is sequentially repeated three times. Repetition of the word اشتعل with a vertical and wavy style shows the existence of a room or an excitement. The points that are after the word اشتعل really help the author in expressing the desired meaning. ${ }^{41}$

\section{e. Jinas (Alliteration)}

\section{${ }^{40}$ Al-Khuli, p. 258.}

${ }^{41}$ Rasoul Ballawy, 'The Phenomenon of Repetition and Its Technical Implications in the Poetry of Dr. Ali Majeed Al-Budairi’, Jurnal Al-Ustath, 1.224 (2018), 1-16. 
Jinas is the similarity or similarity of two words but different in meaning. ${ }^{42}$ The popular term used is alliteration. ${ }^{43}$ Its function and usefulness is to enhance the construction of sentences by displaying the same word, but with different meanings. In its division, jinas is divided into two, namely jinas lafdzi and jinas ma'nawi. Jinas lafdzi can be divided into two, namely jinas tam and ghairu tam. While jinas ma'nawi is also divided into two, namely jinas idhmar and jinas isyarah. ${ }^{44}$ In relation to the repetitions in this study, the researcher will present one of the findings found in the MSD composition. They are jinas tam and jinas ghairu tam.

\section{Jinas Tam (Paronomasia)}

Paronomasia is the similarity or suitability of two words in four terms, namely letters, numbers, calculations, shapes or societies, and their sequences by emphasizing the essence that the two words have different meanings. ${ }^{45}$ In Arabic literature, Paronomasia is often referred to as jinas tam. ${ }^{46}$

Table 11. $5^{\text {th }}$ Section

\begin{tabular}{c|l}
\hline Text & \multicolumn{1}{c}{ Meaning } \\
\hline وأمه التي هي في المخاوف آمنة، السيدة الكريمة آمنة & $\begin{array}{l}\text { As well as his mother who always felt safe and } \\
\text { secure, even there are a lot of terrible things. } \\
\text { She was Sayyidah Aminah }\end{array}$ \\
\hline
\end{tabular}

Table 12. $7^{\text {th }}$ Section

\begin{tabular}{c|l}
\hline Text & \multicolumn{1}{c}{ Meaning } \\
\hline من خواص الأمة، أن يحضر عند وضعه أمة & $\begin{array}{l}\text { On the chosen people, who were waiting for the } \\
\text { seconds of their birth (aminah) }\end{array}$ \\
\hline
\end{tabular}

Table 13. $13^{\text {th }}$ Section

\begin{tabular}{l|l}
\hline Text & \multicolumn{1}{c}{ Meaning } \\
\hline تشهد فها الذات للذات & $\begin{array}{l}\text { The moment of the essence gives his witness to the } \\
\text { majesty of the Essence (of Allah). }\end{array}$ \\
\hline
\end{tabular}

Some of the pieces of Maulid of Simtud Durar above are examples of style of language of Jinas Tam or Paronomasia. The effect caused by the author on his funding is the attitude of caution in interpreting a word. That is, if the reader does not understand

42 Ahmad Al-Hasyimi, Jawahirul Balaghoh Fi Al-Ma'ani Wa Al-Bayan Wa Al-Badi' (BeirutLebanon: Al-Maktabah Al-'Ashriyyah, 1994), p. 343.

${ }^{43}$ Syihabuddin Qalyubi, Stilistika Bahasa Dan Sastra Arab (Yogyakarta: Karya Media, 2013), p. 126.

\footnotetext{
${ }^{44}$ Al-Hasyimi, p. 343-350

45 Al-Hasyimi, p. 344
} 
the context of the maulid above, it is very likely that the reader interprets each of the above words with the same meaning. In fact, it is clear that each of the two words composed above has different meanings. There is the beauty of the composition of the maulid. In addition, the author is able to create a specific musical atmosphere that leads to the desired meaning.

To strengthen this analysis, it is better for the researcher to display one form of Paronomasia style quoted from al-Quran surah Ar-Rum verse 55: ${ }^{47}$

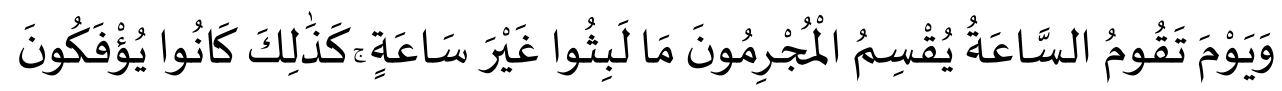

"And on that Day when the Hour will come to pass, the wicked shall swear that they had stayed (in the world) no more than an hour. Thus they used to be deceived in the life of the world"

The word السـاعة is repeated twice in one verse. The existence of the word in the verse makes the reader or listener to be more careful in interpreting a verse. In addition, the verse also gives the horror effect to the listener when hearing the Day of Judgment.

As a comparison, the researcher will explain one of Abu al-'Ala al-Ma'arri's paronomasia style in his book al-Fusul wa al-Ghayat:

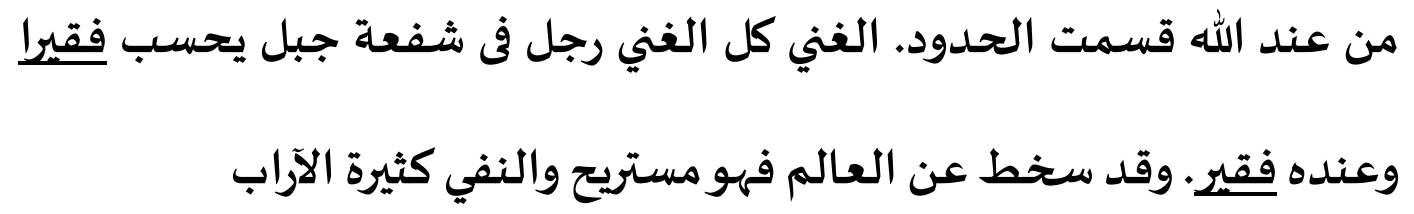

The author repeats the word فقير twice. The first word means poor, while the second word means well. The purpose of lecturing used by the author here is to play with words and at the same time want to show the beauty of bayani and badi'i (muhassinat bayaniyah wa al-badi'iyyah) which are commonly used to obtain the desired intention. ${ }^{48}$

\section{Jinas Ghairu Tam}

${ }^{46}$ Qalyubi, p. 126

${ }^{47}$ Al-Hasyimi, p. 344.

${ }^{48}$ Zahra Q.Madoni, 'The Phenomenon of Repetition When Abu Alaa Al-Ma'ari in "Al-Fushul and Al-Ghoyat"”, Jurnal Adab Al-Kufa, 1.34 (2018), 303-22. 
Jinas Ghairu Tam is a form that has not fulfilled the four conditions (letters, counts, shapes, sequences). That can be due to additions, both at the beginning, middle, and end of words. ${ }^{49}$

Table 10. $7^{\text {th }}$ Section

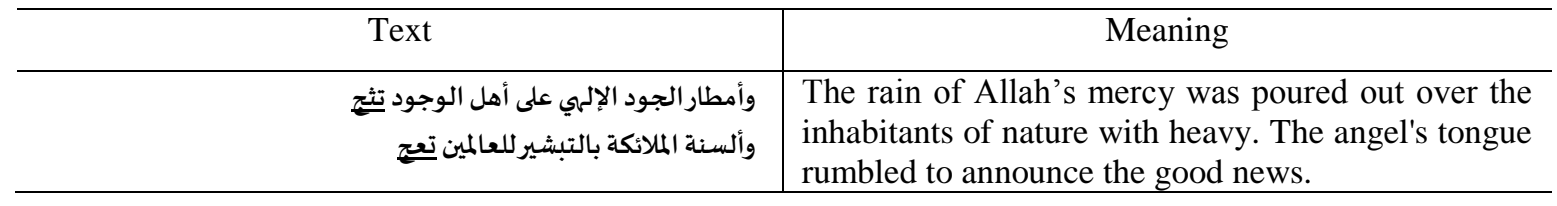

In the above piece of maulid there is a jinas ghairu tam style of language aimed at the word تثج (heavy) and the word تعج (rumbling). The desired effect of the author on the style of language is the beauty of sentence construction is almost the same. In other words the author brings up the musicalization in the text section. In addition, the reader will think that the two words have the same meaning, but clearly different.

As a comparison, researchers also took shaheed from the Al-Quran. The shaheed used by researchers to strengthen the style of jinas ghairu tam is al-Quran surah Ghafir verse $75:^{50}$

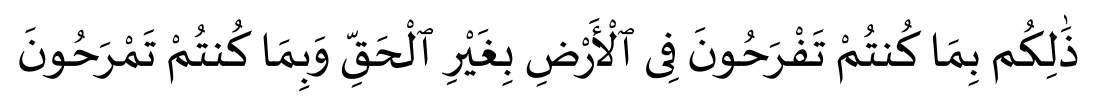

"That is because you rejoice on the earth incorrectly and because you always rejoice in disobedience".

The above verse is one of the models of Jinas Ghairu Tam. It is said ghairu tam because there is one different letter in two almost identical words, the words تفرحون and The difference is seen in the fa 'fi'il of the two verbs. The first is the letter $f a$ ' and the second is the letter mim. The beauty of the musicalisation of the verse is obtained from the similarity of the two words that are balanced and ending with the same letter, namely nun. However, the two meanings of the word differ in their usage.

\section{Conclusion}

All these forms of repetition show the beauty and high quality of the style of language used by Habib Ali al-Habsyi. The characteristic and contribution of this study is

\footnotetext{
${ }^{49}$ Al-Hasyimi, p. 345

${ }^{50}$ Al-Hasyimi, p. 345.
} 
that through the repetition the author of MSD concretely is able to describe abstract meanings and thoughts, especially in aspects that emphasize occult things and extraordinary events beyond human capabilities. In addition, this study emphasizes that something is visible and concrete can strengthen meaning and have a greater effect in the heart and mind. This review of repetition confirms that repetition as a form is very different from repetition as a form of weakness of novice writers. That is, repetition in this case is a form of repetition with the aim of emphasizing or prioritizing certain constituents, not repetition that has not a clear function as an instrument of importance. Repetition requires the author's creativity in accuracy when choosing a word that wants to be repeated. This is very important in optimizing the function of repetition which incidentally helps in emphasizing intentions and giving certain effects. The patterns and forms of repetition further emphasize the significance of stylistic studies in general and studies of repetition specifically in the discourse of literary discourse. Repetition is one of the artistic phenomena and part of the most prominent linguistic style that is able to manifest semantic and aesthetic dimensions in literary discourse. In the eyes of literature, repetition needs to be studied continuously to find continuity between literature and linguistics. So, it is interesting that this research is continued by using an interdisciplinary or multidisciplinary approach, for example the psycholinguistic approach, literary psychology, and combined with stylistic studies.

\section{Acknowledgment}

I cannot express my gratitude enough to my teachers for their continued support and encouragement: Dr. KH. Abdul Ghofur Maemun, Chairperson of STAI ALANWAR; Dr. Najib Bukhori and Moh. Asif, M.Ud; My supervisor is also to al Bayan journal reviewers who give many suggestions and directions in this research. I express my sincere thanks for my advice and direction, so that this research can take place and published.

\section{References}

Abidin, Achmad Syukron, 'Nilai-Nilai Aqidah Dan Ahlak Dalam Kitab Simtut Durar Karya Habib Ali Bin Muhammad Al-Habsyi', El-Wasathiya : Jurnal Studi Agama, 7.1 (2019), 1-25

Al-Hasyimi, Ahmad, Jawahirul Balaghoh Fi Al-Ma'ani Wa Al-Bayan Wa Al-Badi' (Beirut-Lebanon: Al-Maktabah Al-'Ashriyyah, 1994) 
Al-Khuli, Muhammad Ali, A Dictionary of Theoretical Linguistics (Lebanon: Librairie du Libani, 1982)

Alfianika, Ninit, 'Bahasa Betawi Dan Gaya Bahasa Repetisi Dalam Ceramah Ustad Yusuf Mansur Progam Wisata Hati Di ANTV', Jurnal Gramatika, 1.1 (2015), 11122

Ali, Habibullah Ali Ibrahim, 'Dirasah Al-Uslub Wa Al-Uslubiyah Fi Naqd Al-Araby', LiNGUA: Jurnal Ilmu Bahasa Dan Sastra, $10.1 \quad$ (2015), 45-54 <https://doi.org/10.18860/ling.v10i1.3033>

Ballawy, Rasoul, 'The Phenomenon of Repetition and Its Technical Implications in the Poetry of Dr. Ali Majeed Al-Budairi', Jurnal Al-Ustath, 1.224 (2018), 1-16

Dicka Maretta, Arina, Elisabeth Nugrahani Eko Wardani, and Atikah Anindiyarini, 'Analisis Stilistika Dan Nilai Pendidikan Karakter Dalam Lirik-Lirik Lagu Fourtwnty Album Lelaku Serta Relevensinya Sebagi Bahan Ajar Bahasa Indonesia Tingkat SMA', BASASTRA Jurnal Pendidikan Bahasa, Sastra Indonesia Dan Pengajarannya, 6.2 (2019), 31-39

Fadhil, Abdul Karim, 'Al-Tikrar Fi Syi'ri Ibnu Jabir Al-Dharir Al-Andalusi', Jurisprudence Faculty Journal, 19, 2014, 186-223

Farsi, Roghayeh, 'Repetition and Reactance in Graham's 'Underneath" Poems', International Journal of Applied Linguistics and English Literature, 6.6 (2017), 223-34 <https://doi.org/10.7575/aiac.ijalel.v.6n.6p.223>

Fatoni, Nur Rochmah, 'Kekhasan Diksi Valentin Simajuntak Pada Piala Presiden 2017', Adabiyyat: Jurnal Bahasa Dan Sastra, I.2 (2017), 223-47

Fauzi, Nur, Syamsul Hadi, and Thoyyib, 'Bentuk Repetisi Linguistik Dalam Al-Quran', LiNGUA: Jurnal Ilmu Bahasa Dan Sastra, 9.1 (2014), 31-40

Habib, 'Stilistika Pengulangan Sebagai Trasnfer Ideologi (Telaah Atas Pidato Politik Sayyed Hasan Nasrullah)', TAMADDUN: Jurnal Kebudayaan Dan Sastra Islam, 14.1 (2014), 63-80

Hadi, Nadia Fathi, 'Repetition Significance in Ibn Zaidoun's Noun-Rhymed Poem', Jurnal Adab AL Rafidayn, 68, 2013, 149-78

Hamid, Saeed Abdul, 'Impact of Redundancy in the Quranic Text Consistency Study in Light Text Linguistics', Al-Adab Journal, 129, 2019, 791-808

Hidayat, Saiful, 'Kalimat Berita Dalam Kitab Maulid Simtudduror', SKRIPSI Jurusan Sastra Arab-Fakultas Sastra UM (Universitas Negeri Malang, 2015)

Jalil, Firas Yahya Abdul, 'The Repetition of the Words of Quranic Texts and Their Impact on the Diversity of Meaning', Anbar University Journal of Islamic Sciences, 10.40 (2019), 1-28

Johnstone, Barbara, Repetition in Arabic Discourse: Paradigms, Syntagms, and the 
Ecology of Language (Amsterdam: John Benjamins Publishing, 1991)

Keraf, Gorys, Diksi Dan Gaya Bahasa (Jakarta: Gramedia Pustaka Utama, 2010)

Mahsun, M.S, Metode Penelitian Bahasa Metode Penelitian Bahasa: Tahapan Strategi Metode Dan Tekniknya (Jakarta: Raja Grafindo Persada, 2014)

Pamungkas, Sidiq Aji, and Kundharu Saddono, 'Repetisi Dan Fungsinya Dalam Novel Di Tanah Lada Karya Ziggy Zezsyazeoviennazabrizkie: Analisis Stilistika', METASASTRA: Jurnal Penelitian Sastra, 11.1 (2018), 113

Parwati, Edin, 'Kohesi Leksikal Repetisi Pada Wacana Wayang Durangpo Dalam Surat Kabar Harian Jawa Pos Edisi Februari-April 2010', Jurnal Artikulasi, 12.2 (2011), 807-16

Purdi, Rohmat Anang, 'Isti'arah Wa Jamaaliha Fi Simtud Durar', Thesis (UIN Sunan Ampel Surabaya, 2016)

Q.Madoni, Zahra, 'The Phenomenon of Repetition When Abu Alaa Al-Ma'ari in "AlFushul and Al-Ghoyat"', Jurnal Adab Al-Kufa, 1.34 (2018), 303-22

Qalyubi, Syihabuddin, Stilistika Al-Qur'an Pengantar Orientasi Studi Al-Qur'an, 2nd edn (Yogyakarta: Belukar, 2008)

—_ Stilistika Bahasa Dan Sastra Arab (Yogyakarta: Karya Media, 2013)

Rangbar, Jawad, and Ameen Nadhri, 'Repetition and Its Styles in the Complete Poetic Collectioe', Basic Education College Magazine For Educational and Humanities Sciences, 37, 2018, 52-65

Ratna, Nyoman Kutha, Stilistika: Kajian Puitika Bahasa, Sastra, Dan Budaya (Yogyakarta: Pustaka Pelajar, 2013)

Ridlo, Abdullah, 'Kompleksitas Gaya Bahasa Diwan Al-Imam Asy-Syafi'i (Studi Analisis Stilistika)', Thesis (Yogyakarta : Pascasarjana UIN Sunan Kalijaga, 2017)

Rosmini, Sugit Zulianto, and Sitti Harisah, 'Diksi Dan Gaya Bahasa Syair Lagu Karya Didi Kempot', Jurnal Bahasantodea, 5.2 (2017), 92-101

Susilowati, Rifka Diana, 'Al Suja' Fi Simth Al Durar : Dirasah Balaghiyah', Thesis (UIN Sunan Ampel Surabaya, 2014)

Syahid, Akhmad, and Ika Selviana, 'Gaya Bahasa Dalam Lirik Lagu Shalawat Nissa Sabyan Dan Implikasinya Terhadap Studi Stilistika (Ilmu Uslub)', Al-Fathin: Jurnal Bahasa Dan Sastra Arab, 1 (2019), 193-207

Tarigan, Henry Guntur, Pengajaran Gaya Bahasa (Bandung: Angkasa, 2013)

Wijana, I Dewa Putu, 'Repetisi Dalam Karangan Mahasiswa Dan Penanganannya', Humaniora, 18.1 (2006), 37-45 
Yassin, Moataz Qusay, 'The Aesthetic of Repetition in the Poetry of Ahmed Matar', The Arab Gulf, 46.1-2 (2018), 206-37 